\title{
A monoklonális gammopathia szemészeti jelei és szövődményei
}

\author{
42 beteg 84 szemének vizsgálata
}

\author{
Kormányos Kitti dr. ${ }^{1,2}$ - Kovács Klaudia dr. ${ }^{1}$ - Németh Orsolya dr. ${ }^{3}$ \\ Tóth Gábor dr. ${ }^{1}$ - Sándor Gábor László dr. ${ }^{1}$ - Csorba Anita dr. ${ }^{1}$ \\ Czakó Cecília Nóra dr. ${ }^{1}$. Langenbucher Achim dr. ${ }^{4}$ \\ Nagy Zoltán Zsolt dr. ${ }^{1}$ - Varga Gergely dr. ${ }^{5}$ - Gopcsa László dr. ${ }^{6}$ \\ Mikala Gábor dr. ${ }^{6}$. Szentmáry Nóra dr. ${ }^{1,7}$
}

\author{
${ }^{1}$ Semmelweis Egyetem, Általános Orvostudományi Kar, Szemészeti Klinika, Budapest \\ ${ }^{2}$ Magyar Honvédség Egészségügyi Központ, Szemészeti Osztály, Budapest \\ ${ }^{3}$ Markusovszky Egyetemi Oktatókórház, Szemészeti Osztály, Szombathely \\ ${ }^{4}$ Experimental Ophthalmology, Saarland University, Homburg/Saar, Germany
}

${ }^{5}$ Semmelweis Egyetem, Általános Orvostudományi Kar, III. Belgyógyászati és Hematológiai Klinika, Budapest

${ }^{6}$ Dél-pesti Centrum Kórház - Országos Hematológiai és Infektológiai Intézet, Hematológiai és Őssejt-transzplantációs Osztály, Budapest

${ }^{7}$ Dr. Rolf M. Schwiete Center for Limbal Stem Cell and Congenital Aniridia Research, Saarland University, Homburg/Saar, Germany

Célkitüzés: A monoklonális gammopathia szemészeti jeleinek és szövődményeinek vizsgálata.

Betegek és módszerek: Két nagy budapesti hematológiai ellátóhely 1999 és 2020 között diagnosztizált és/vagy kezelt, monoklonális gammopathiát mutató betegeit vizsgáltuk (42 beteg 84 szeme, $42,86 \%$ férfi; átlagéletkor $63,83 \pm$ 10,76 év). A hematológiai diagnózis 3 esetben bizonytalan jelentőségú monoklonális gammopathia, 34 esetben myeloma multiplex, 3 esetben parázsló myeloma, 1-1 esetben Waldenström-macroglobulinaemia és amyloidosis voltak. Kontrollcsoportként véletlenszerúen kiválasztott, hasonló korcsoportú, hematológiai betegség nélküli egyéneket vizsgáltunk (43 beteg 86 szeme, 32,56\% férfi; átlagéletkor 62,44 $\pm 11,89$ év). A szemészeti vizsgálat előtt minden személy kitöltötte a Szemfelszíni Betegség Index (OSDI-) kérdőívet. A szemészeti vizsgálat során a látóélesség vizsgálata mellett pupillatágítást követően réslámpás vizsgálatot végeztünk.

Eredmények: Monoklonális gammopathiában az OSDI-érték szignifikánsan magasabb volt, mint a kontrollokban $(\mathrm{p}=0,002)$. Gammopathiában 3 beteg 5 szeménél $(5,95 \%)$ találtunk potenciális szaruhártya-immunglobulinlerakódást. Gammopathiában szárazszem-betegség 66,67\%-ban, szürke hályog 55,95\%-ban, Meibom-mirigy-diszfunkció 20,24\%-ban, hátsó kérgi szürke hályog 19,05\%-ban, egyéb szaruhártyahegek és -homályok 17,86\%-ban, krónikus szemhéjgyulladás 14,29\%-ban, szemészeti eltérés hiánya 11,90\%-ban, macula- és/vagy retinadrusen 9,52\%-ban, szaruhártya-immunglobulinlerakódás 5,95\%-ban, epiretinalis membrán 5,95\%-ban, korábbi szürkehályog-mútét 5,95\%ban, glaucoma 4,76\%-ban, Fuchs-dystrophia 2,38\%-ban, perifériás retinadegeneráció 2,38\%-ban, chorioidea naevus 2,38\%-ban, diabeteses retinopathia $1,19 \%$-ban, arteria centralis retinae elzáródás $1,19 \%$-ban, vena centralis retinae ágelzáródás $1,19 \%$-ban, amblyopia $1,19 \%$-ban volt kimutatható. A szárazszem-betegség $(\mathrm{p}=0,002)$, a hátsó kérgi szürke hályog $(\mathrm{p}=0,001)$, a szürke hályog $(\mathrm{p}<0,00001)$ és az egyéb szaruhártyahegek és -homályok $(\mathrm{p}=0,01)$ szignifikánsan magasabb arányban fordultak elő a monoklonális gammopathiát mutató betegekben, mint a kontrollokban.

Következtetés : Monoklonális gammopathiában a szárazszem-betegség és a szürke hályog a leggyakoribb szemészeti eltérés. A monoklonális gammopathia potenciális szemészeti jelei és szövődményei miatt javasoljuk a betegek évenkénti szemészeti ellenőrzését, életminőségük javítása érdekében.

Orv Hetil. 2021; 162(38): 1533-1540.

Kulcsszavak: MGUS, monoklonális gammopathia, szaruhártya, paraproteinaemiás keratopathia 


\title{
Ocular signs and comorbidities in monoclonal gammopathy
}

\author{
Analysis of 84 eyes of 42 subjects
}

Objective: To examine ocular signs and ocular comorbidities in monoclonal gammopathy.

Patients and methods: We analyzed patients from two large referral hematology centers in Budapest, who were diagnosed and/or treated with monoclonal gammopathy between 1997 and 2020 (84 eyes of 42 patients, 42.86\% male, mean age $63.83 \pm 10.76$ years). Before the ophthalmic examination, the subjects filled in the Ocular Surface Disease Index (OSDI) questionnaire. Ophthalmic examination included visual acuity test and slit-lamp examination following dilation of the pupil.

Results: OSDI scores were significantly higher in subjects with monoclonal gammopathy than in controls $(\mathrm{p}=0.002)$. Among gammopathy subjects, we observed potential corneal immunoglobulin deposition in 5 eyes of 3 patients $(5.95 \%)$. In gammopathy subjects, there was dry eye disease $(66.67 \%)$, cataract $(55.95 \%)$, Meibomian gland dysfunction $(20.24 \%)$, posterior cortical cataract $(19.05 \%)$, corneal scars and degenerations $(17.86 \%)$, chronic blepharitis (14.29\%), absence of ocular complaint (11.90\%), macular or retinal drusen (9.52\%), corneal immunoglobulin deposition (5.95\%), epiretinal membrane (5.95\%), previous cataract surgery (5.95\%), glaucoma (4.76\%), Fuchs dystrophy $(2.38 \%)$, peripheral retinal degeneration $(2.38 \%)$, chorioideal naevus $(2.38 \%)$, diabetic retinopathy $(1.19 \%)$, central retinal artery occlusion $(1.19 \%)$, central retinal vein branch occlusion (1.19\%) and amblyopia (1.19\%). The proportion of dry eye disease $(\mathrm{p}=0.002)$, posterior cortical cataract $(\mathrm{p}=0.001)$, cataract $(\mathrm{p}<0.00001)$, and corneal scars and degenerations $(\mathrm{p}=0.01)$ were significantly higher in gammopathy subjects than in controls.

Conclusion: Dry eye disease and cataracts are the most common ocular comorbidities in patients with monoclonal gammopathy. Therefore, due to the potential ocular signs and comorbidities of monoclonal gammopathy, we suggest a regular, yearly ophthalmic checkup of these patients to improve their quality of life.

Keywords: MGUS, monoclonal gammopathy, cornea, paraproteinaemic keratopathy

Kormányos K, Kovács K, Németh O, Tóth G, Sándor GL, Csorba A, Czakó CN, Langenbucher A, Nagy ZZS, Varga G, Gopcsa L, Mikala G, Szentmáry N. [Ocular signs and comorbidities in monoclonal gammopathy. Analysis of 84 eyes of 42 subjects]. Orv Hetil. 2021; 162(38): 1533-1540.

(Beérkezett: 2021. február 23.; elfogadva: 2021. március 14.)

\section{Rövidítések}

ACG $=($ angle-closure glaucoma $)$ zárt zugú glaucoma; AMD = (age-related macular degeneration) időskori maculadegeneráció; $\mathrm{BCVA}=$ (best corrected visual accuity) legjobb korrigált látóélesség; Ig = immunglobulin; ITK = immuntactoid keratopathia; $\log$ MAR $=($ logarithm of the minimum angle of resolution) a minimális felbontási szög logaritmusa; MGOS = monoklonális gammopathia ocularis szignifikanciával; MGUS = (monoclonal gammopathy of undetermined significance) bizonytalan jelentőségú monoklonális gammopathia; $M M=$ myeloma multiplex; OAG = (open-angle glaucoma) nyílt zugú glaucoma; OCT $=$ (optical coherence tomography) optikaikoherencia-tomográfia; OGYÉI = Országos Gyógyszerészeti és Élelmezés-egyészségügyi Intézet; OSDI $=($ Ocular Surface Disease Index) Szemfelszíni Betegség Index; PKP = (penetrating keratoplasty) perforáló keratoplasztika; SLE = szisztémás lupus erythematosus

A klinálisplazmasejt-betegségekbe tartozó monoklonális gammopathiák spektrumába a bizonytalan jelentőségú monoklonális gammopathia (a továbbiakban: MGUS), a szoliter plasmocytoma, a Waldenström-macroglobulinaemia, az aszimptomatikus vagy szimptomatikus myeloma multiplex (MM) és a plazmasejtes leukaemia tartozik. Közös jellemzőjük a monoklonális fehérjeszaporulat, a gammopathia $[1,2]$.
Az MGUS-t praemalignus állapotnak tekinthetjük; három típusa különíthető el: az IgM-MGUS, a non-IgMMGUS (IgA- és IgG-MGUS) és a könnyưlánc-MGUS. A betegség malignizálódása általában aszimptomatikusan (klinikai jelek nélkül) zajlik, úgynevezett parázsló fázisokon keresztül. Az IgM-MGUS átalakulhat Waldenströmmacroglobulinaemiává, a non-IgM-MGUS MM-mé és a könnyưlánc-MGUS könnyúlánc-myelomává. Az MGUS összes formájából kialakulhat amyloidosis vagy nonHodgkin-lymphoma, amelyek fontos differenciáldiagnosztikai entitások [3].

Az MGUS diagnosztikus kritériumai az International Myeloma Working Group 2015. évi ajánlása alapján a következők: a csontvelő plazmasejtaránya kevesebb mint 10\%; a monoklonális fehérje (M-protein) szérumszintje kevesebb mint $30 \mathrm{~g} / \mathrm{l}$; a malignus B-sejtes betegségekre jellemző szervi károsodás hiánya, melyek a hypercalcaemia, a veseelégtelenség, az anaemia, a csonteltérések [4-6]. Az MGUS előfordulása az életkor előrehaladtával emelkedik, az 50-55 éves populációban 1,7\%, míg a 80 év feletti egyénekben 6,6\% (Kyle és mtsa, 2016) [7].

Monoklonális gammopathiában különböző szervekben figyelhető meg monoklonális fehérje lerakódása, a fehérje okozta szervi károsodás [8]. MM-ben a leggyakrabban a vesék érintettek, az esetek mintegy 27\%-ában 
Életkor (átlag \pm szórás [minimum-maximum]), nem (n [\%]), a Szemfelszíni Betegség Index (Ocular Surface Disease Index [OSDI]) pontértéke (átlag \pm szórás [minimum-maximum]), a legjobb korrigált látóélesség (best corrected visual acuity [BCVA]) (átlag \pm szórás [minimum-maximum]) a kontrollcsoportban és a gammopathiás betegeknél. A p-értékek a Mann-Whitley-féle U-teszt (életkor, OSDI és BCVA) és a $\chi^{2}$-próba (férfiak) eredményét mutatják. Szignifikáns különbséget nem találtunk

\begin{tabular}{lllll}
\hline & Életkor (évek) & Férfiak (n [\%]) & OSDI & BCVA \\
\hline Kontroll & $62,44 \pm 11,89(37-86)$ & $14(32,56 \%)$ & $12,66 \pm 11,00(0-50)$ & $0,94 \pm 0,16(0,06-1,0)$ \\
\hline Gammopathia & $63,83 \pm 10,76(38-80)$ & $18(42,86 \%)$ & $21,51 \pm 18,03(0-65.9)$ & $0,84 \pm 0,24(0,01-1,0)$ \\
\hline p-érték & 0,39 & 0,39 & 0,19 & 0,77 \\
\hline
\end{tabular}

(proteinuria, nephroticus szindróma) [9]. Polyneuropathia az esetek mintegy $5-10 \%$-ában van jelen, jellemzően azoknál a betegeknél, akiknél a paraprotein IgM-természetû [10-12]. A monoklonális immunglobulinok inzulinkötő autoantitestként is szerepelhetnek, inzulin autoimmun szindrómát utánozva [13]. Ritka esetben a monoklonális plazmasejtek a myocardiumot is infiltrálhatják, aminek következtében infiltratív cardiomyopathia alakul ki. A könnyúlánc-amyloidok lerakódása pedig restriktív cardiomyopathiát okozhat [14]. Erciyestepe és mtsai 2584 myelomás betegből 24 esetben számoltak be gastrointestinalis érintettségről, ebből 11 esetben a májban [15]. Ezenkívül dokumentáltak infiltratív bőrbetegséget, paraneoplasiás megbetegedéseket, dermatosisokat, valamint purpurát/pruritust [16].

A gammopathia szemészeti jelei között fellelhetők a kötőhártyában és szaruhártyában lerakódások, akut/ krónikus uveitis [17, 18], maculopathia és foveolaris drusen [19, 20], Doyne retina dystrophia [21], arteria (a.) vagy vena (v.) centralis retinae elzáródás [22], myositis és proptosis [23].

A paraproteinaemiaval társított szaruhártya-lerakódásokat először az 1900-as években kaméleonszerü eltérésekként írták le [24, 25]. Ezek típusosan kétoldali, szürkésfehér, sárgás vagy szürkésbarna, polychromaticus vagy kristályszerú eltérések a szaruhártya bármely rétegében. Az eltérések a szaruhártyában diffúzan vagy fokálisan, centrálisan vagy perifériásan is elhelyezkednek [4].

Az MGUS-ban kialakult szaruhártya-lerakódások számtalan formában megjelenhetnek, ezeket Lisch és mtsai „kaméleonszerü” szaruhártya-lerakódásokként jellemezték. 2012-ben egységes és nemzetközileg elfogadott nevezéktant hoztak létre, mely 5 különböző típusú immuntactoid keratopathiát (ITK) különít el: kristályszerú ITK, rácsszerû ITK, perifériás granuláris ITK, perifériás kötegszerü ITK és perifériás foltszerü ITK. Később, 2016-ban ezt a nevezéktant kibővítették 11 különböző, MGUS okozta paraproteinaemiás keratopathia formára [25].

A monoklonális gammopathiával járó kórképek klinikai megjelenése változatos. Ugyanakkor jelenleg kevés adat áll rendelkezésre a monoklonális gammopathia szemészeti jeleinek és szemészeti társbetegségeinek előfordulásáról. Munkánk célja a monoklonális gammopathia szemészeti jeleinek és szemészeti társbetegségeinek meghatározása volt.

\section{Betegek és módszerek}

Munkánkban a Dél-pesti Centrumkórház - Országos Hematológiai és Infektológiai Intézet, Hematológiai és Őssejt-transzplantációs Osztály és a Semmelweis Egyetem, III. Belgyógyászati és Hematológiai Klinika 1999 és 2020 között monoklonális gammopathiával felismert és kezelt betegeit vizsgáltuk. Kontrollcsoportként véletlenszerüen kiválasztott, azonos korú, hematológiai betegséggel nem rendelkező egyéneket vontunk be. Az Etikai Bizottság engedélyezte vizsgálatunkat (OGYÉI/ $50115 / 2018)$. A vizsgálatban való részvétel önkéntes volt, és minden egyén tájékoztatott beleegyezését adta írásban.

Összesen 85 beteg 170 szemét vizsgáltuk (átlagéletkor 63,13 $\pm 11,30$ év). 42 beteg 84 szeme (42,86\% férfi; átlagéletkor $63,83 \pm 10,76$ év [38-80 éves kor között]) tartozott a monoklonális gammopathiás csoportba, a kontrollok közé pedig 43 beteg 86 szeme (32,56\% férfi; átlagéletkor 62,44 $\pm 11,89$ év [37-86 éves kor között]). A két csoportba tartozó betegek életkora nem különbözött szignifikánsan $(\mathrm{p}=0,39)$ (1. táblázat).

A monoklonális gammopathiás betegcsoportban a diagnózis felállítása és a vizsgálatba való bevonás között 1 esetben $(2,38 \%)$ kevesebb mint 1 év telt el, 21 esetben $(50,00 \%)$ született diagnózis 5 éven belül, 14 esetben (33,33\%) 5-10 éven belül, 6 esetben (14,29\%) több mint 10 éve. A hematológiai diagnózis 3 esetben $(7,14 \%)$ MGUS, 34 esetben (80,95\%) MM, 3 esetben parázsló myeloma $(7,14 \%)$ és 1 -1 esetben $(2,38-2,38 \%)$ amyloidosis, illetve Waldenström-macroglobulinaemia volt.

Az immunglobulinok nehéz lánca tekintetében emelkedett IgG-szintet 29 (69,05\%), IgA-t 9 (21,43\%), IgM-et $2(4,76 \%)$ és IgD-t 1 (2,38\%) esetben találtunk. I személynél $(2,38 \%)$ nehéz lánc termelődése nem volt detektálható. Könnyű láncok esetében emelkedett kappa-lánc-szint 29 esetben $(59,52 \%)$, míg emelkedett lambda-lánc-szint 17 esetben $(40,48 \%)$ volt igazolható.

A monoklonális gammopathiát mutató betegek közül 23 esetben $(54,76 \%)$ korábban osteolyticus csontlaesio került leírásra, 12 esetben $(28,57 \%)$ veseérintettség, 2 esetben (4,76\%) gerincvelö-érintettség, I esetben $(2,38 \%)$ polyneuropathia, 1 esetben $(2,38 \%)$ a nervus medianus beszűrődése igazolódott. Egyéb szervi érintettség 17 betegnél (40,48\%) nem volt igazolt. A vizsgálatba bevonást megelőzően 27 beteg $(64,29 \%)$ esett át 
autológőssejt-transzplantáción, és 38 beteg (90,48\%) kapott daganatellenes gyógyszeres kezelést a hematológiai dokumentáció alapján.

A gammopathiás betegcsoportban magasvérnyomásbetegség 29 (69,05\%), 2-es típusú cukorbetegség 7 (16,67\%), szívritmuszavar $4(9,52 \%)$, gastrooesophagealis reflux $3(7,14 \%)$, korábbi akut myocardialis infarctus $3(7,14 \%)$, mélyvénás thrombosis $2(4,76 \%)$, asztma 2 $(4,74 \%)$, emlőcarcinoma $2(4,74 \%)$, méhnyakrák 2 $(4,74 \%)$, benignus prostata-hyperplasia, prostatatumor, endometriosis, Raynaud-szindróma, tüdőembolia, stroke, rheumatoid arthritis, szisztémás lupus erythematosus (SLE), endometriumcarcinoma, laphámrák, hyperthyreosis, Sjögren-szindróma 1-1 esetben (2,38\%) fordult elö.

A kontrollcsoportban magasvérnyomás-betegség 16 (37,21\%), 2-es típusú cukorbetegség 6 (13,95\%), pitvarfibrilláció $2(4,65 \%)$, gastrooesophagealis reflux 1 $(2,32 \%)$, prostatatumor $1(2,32 \%)$ és vastagbélrák 1 $(2,32 \%)$ egyénnél szerepelt az anamnézisben.

A szemészeti vizsgálat előtt a gammopathiás és a kontrollcsoport betegei is kitöltötték a Szemfelszíni Betegség Index (OSDI - Ocular Surface Disease Index) kérdőívet (a szemfelszíni betegség besorolási tartományai: normális [0-12 pont], enyhe [13-22 pont], középsúlyos [2332 pont] és súlyos [33-100 pont]) szemfelszíni betegség), valamint részletes szemészeti anamnézisfelvételt végeztünk. A szemészeti vizsgálat részeként refraktometria, a legjobb korrigált látóélesség (BCVA) felvétele, Goldmann-féle applanációs tonometria és pupillatágításban végzett réslámpás vizsgálat történt. Ideghártya-eltérés esetén optikaikoherencia-tomográfiát (OCT; AngioVue OCTA, RTVue XR Avanti, Optovue, Fremont, CA, Amerikai Egyesült Államok) végeztünk.

Az adatok statisztikai elemzéséhez Mann-Whitney-féle U-tesztet és $\chi^{2}$-próbát végeztünk.

\section{Eredmények}

A monoklonális gammopathiás és a kontrollszemélyek adatait a 2. és 3. táblázat foglalja össze.

Az OSDI-kérdőív kiértékelése alapján a hematológiai betegek 14 esetben (33,33\%) a normális, 11-ben (26,19\%) az enyhe, 6-ban (14,29\%) a középsúlyos és 11 ben $(26,19 \%)$ a súlyos szemfelszíni betegségtartományba voltak besorolhatók. A kontrollcsoport betegei közül 27 személy $(62,79 \%)$ a normális, $7(16,28 \%)$ az enyhe, 7 (16,28\%) a középsúlyos és $2(4,65 \%)$ a súlyos szemfelszíni betegségtartományba esett. Az OSDI-érték szignifikánsan magasabb volt a monoklonális gammopathiás csoportban, mint a kontrolloknál $(\mathrm{p}=0,02)$.

A monoklonális gammopathiát mutató csoport szemészeti anamnézisében nem találtunk szemészeti betegséget 38 esetben $(45,24 \%)$. Szárazszem-betegség 38 $(45,24 \%)$, szürke hályog $11(13,10 \%)$, korábban elvégzett szürkehályog-műtét $5(5,95 \%)$, hátsó kérgi szürke hályog 4 (4,76\%), glaucoma 4 (4,76\%), korábbi perforá-
2. táblázat Szemészeti diagnózisok a kontroll- és a gammopathiás csoportba tartozó személyek szemészeti anamnézisében (n [\%]). A p-értékek a $\chi^{2}$-próba eredményét mutatják, a szignifikáns értékeket kurzív betútípussal jelöltük. „0” értéknél $\chi^{2}$-próba nem volt végezhető

\begin{tabular}{lccl}
\hline Szemészeti diagnózis & Kontroll & Gammopathia & p-érték \\
\hline Szárazszem-betegség & $17(19,77 \%)$ & $38(45,24 \%)$ & 0,0003 \\
Perforáló keratoplasztika & 0 & $1(1,90 \%)$ & - \\
Glaucoma & $4(4,65 \%)$ & $4(4,76 \%)$ & 0,97 \\
Korábbi szürkehályog-mútét & $12(13,95 \%)$ & $5(5,95 \%)$ & 0,08 \\
Szürke hályog & $11(12,79 \%)$ & $11(13,10 \%)$ & 0,95 \\
Hátsó kérgi szürke hályog & $1(1,16 \%)$ & $4(4,76 \%)$ & 0,16 \\
Korábbi szemészeti & $22(25,58 \%)$ & $38(45,24 \%)$ & 0,007 \\
diagnózis nélkül & & & \\
\hline Összes & $86(100 \%)$ & $84(100 \%)$ & \\
\hline
\end{tabular}

3. táblázat |A szemvizsgálatot követô szemészeti diagnózisok a kontroll- és a gammopathiás csoportban (n [\%]). A p-értékek a $\chi^{2}$-próba eredményét mutatják, a szignifikáns értékeket kurzív betútípussal jelöltük. „0” értéknél $\chi^{2}$-próba nem volt végezhető

\begin{tabular}{|c|c|c|c|}
\hline Szemészeti diagnózis & Kontroll & Gammopathia & p-érték \\
\hline $\begin{array}{l}\text { Szárazszem-betegség } \\
\text { (OSDI alapján) }\end{array}$ & $32(37,21 \%)$ & $56(66,67 \%)$ & 0,002 \\
\hline Meibom-mirigy-diszfunkció & $10(11,63 \%)$ & $17(20,24 \%)$ & 0,12 \\
\hline Krónikus szemhéjgyulladás & $16(18,60 \%)$ & $12(14,29 \%)$ & 0,44 \\
\hline $\begin{array}{l}\text { Egyéb szaruhártyahegek és } \\
\text {-homályok }\end{array}$ & $5(5,81 \%)$ & $15(17,86 \%)$ & 0,01 \\
\hline $\begin{array}{l}\text { Szaruhártya-immunglobu- } \\
\text { linlerakódás }\end{array}$ & 0 & $5(5,95 \%)$ & - \\
\hline Fuchs-dystrophia & $2(2,33 \%)$ & $2(2,38 \%)$ & 0,98 \\
\hline Glaucoma & $4(4,65 \%)$ & $4(4,76 \%)$ & 0,97 \\
\hline $\begin{array}{l}\text { Korábbi szürkehályog- } \\
\text { mútét }\end{array}$ & $12(13,95 \%)$ & $5(5,95 \%)$ & 0,08 \\
\hline Hátsó kérgi szürke hályog & $3(3,49 \%)$ & $16(19,05 \%)$ & 0,001 \\
\hline Szürke hályog & $17(19,76 \%)$ & $47(55,95 \%)$ & $<0,00001$ \\
\hline Epiretinalis membrán & $2(2,33 \%)$ & $5(5,95 \%)$ & 0,23 \\
\hline Időskori maculadegeneráció & 0 & 0 & - \\
\hline Macula- vagy retinadrusen & $16(18,60 \%)$ & $8(9,52 \%)$ & 0,08 \\
\hline Maculalyuk & 0 & 0 & - \\
\hline Diabeteses retinopathia & $4(4,65 \%)$ & $1(1,19 \%)$ & 0,18 \\
\hline Perifériás retinadegeneráció & $4(4,65 \%)$ & $2(2,38 \%)$ & 0,42 \\
\hline $\begin{array}{l}\text { Arteria centralis retinae } \\
\text { elzáródás }\end{array}$ & 0 & $1(1,19 \%)$ & - \\
\hline $\begin{array}{l}\text { Vena centralis retinae } \\
\text { ágelzáródás }\end{array}$ & 0 & $1(1,19 \%)$ & - \\
\hline Chorioidea naevus & 0 & $2(2,38 \%)$ & - \\
\hline Chorioretinitis utáni heg & 0 & 0 & - \\
\hline Amblyopia & $1(1,16 \%)$ & $1(1,19 \%)$ & 0,98 \\
\hline Szemészeti eltérés nélkül & $14(16,28 \%)$ & $10(11,90 \%)$ & 0,41 \\
\hline Összes & $86(100 \%)$ & $84(100 \%)$ & \\
\hline
\end{tabular}

OSDI = Szemfelszíni Betegség Index 
ló keratoplasztika (PKP) l (1,90\%) esetben volt ismert. A monoklonális gammopathiás betegek 3 beteget magában foglaló MGUS-alcsoportjában (6 szem, korábbi szisztémás kortikoszteroidkezelés nélkül) szürke hályog 2 (2,88\%), hátsó kérgi szürke hályog 4 (4,76\%) szemnél került korábban leírásra, illetve szerepelt az anamnézisben. Egy esetben sem került sor korábban szürkehályogmütétre.

A kontrollcsoportban nem került leírásra korábbi szembetegség 22 szem esetében $(25,58 \%)$. Szárazszembetegség 17 (19,77\%), korábban elvégzett szürkehályog-mütét 12 (13,95\%), szürke hályog 11 (12,79\%), glaucoma 4 (4,65\%) és hátsó kérgi szürke hályog 1 szemnél $(1,16 \%)$ szerepelt a szemészeti anamnézisben.

A szemészeti anamnézisben a szárazszem-betegség diagnózisa $(\mathrm{p}=0,0003)$ és a korábbi szembetegség diagnózisa $(\mathrm{p}=0,007)$ szignifikánsabban gyakoribb volt a monoklonális gammopathiát mutató betegcsoportban, mint a kontrolloknál.

A hematológiai betegeknél a BCVA 0,84 $\pm 0,24(\log -$ MAR $0,1 \pm 0,24)$, míg a kontrollcsoportban 0,94 $\pm 0,16$ $(\log$ MAR $0,1 \pm 0,16)$ volt. A BCVA tekintetében nem volt szignifikáns különbség a két csoport között a vizsgálat időpontjában $(\mathrm{p}=0,77)$.

A gammopathiás betegcsoportban 28 beteg 46 szemének (54,76\%) BCVA-ja 1,0 (0,0 logMAR), 24 beteg 37 szemének $(44,05 \%)$ BCVA-ja 0,2-0,9 között $(0,1-$ 0,7 logMAR) volt, 1 beteg 1 szemének (1,19\%) nem volt táblaolvasása. A kontrollcsoport betegei között a betegek nagy többségének, 68 szemnek $(79,07 \%)$ a BCVA-ja 1,0 (0,0 logMAR), 10 egyén 12 szemének (13,95\%) BCVA-ja 0,8-0,9 (0,1 logMAR), 5 beteg 5 szemének (5,81\%) BCVA-ja 0,2-0,7 (0,2-0,5 logMAR) volt, és 1 beteg 1 szemének $(1,16 \%)$ nem volt táblaolvasása.

A szemészeti vizsgálati eredmények alapján a monoklonális gammopathiás csoportban 56 esetben (66,67\%) szárazszem-betegség, 47 esetben $(55,95 \%)$ szürke hályog, 17 esetben $(20,24 \%)$ Meibom-mirigy-diszfunkció, 16 esetben $(19,05 \%)$ hátsó kérgi szürke hályog, 15 esetben $(17,86 \%)$ egyéb szaruhártyahegek és -homályok, 12 esetben (14,29\%) krónikus szemhéjgyulladás, 10 esetben (11,90\%) szemészeti eltérés hiánya, 8 esetben $(9,52 \%)$ macula- és/vagy retinadrusen, 5 esetben $(5,95 \%)$ szaruhártya-immunglobulinlerakódás, 5 esetben $(5,95 \%)$ epiretinalis membrán, 5 esetben $(5,95 \%)$ korábbi szürkehályog-mútét, 4 esetben $(4,76 \%)$ glaucoma, 2 esetben $(2,38 \%)$ Fuchs-dystrophia, 2 esetben $(2,38 \%)$ perifériás retinadegeneráció, 2 esetben $(2,38 \%)$ chorioidea naevus, 1 esetben $(1,19 \%)$ diabeteses retinopathia, 1 esetben $(1,19 \%)$ a. centralis retinae elzáródás, 1 esetben $(1,19 \%)$ v. centralis retainae ágelzáródás, 1 esetben $(1,19 \%)$ amblyopia volt igazolható.

A gammopathiás betegeknél potenciális cornealis immunglobulin-lerakódást 3 beteg 5 szeménél $(5,95 \%)$ figyeltünk meg (1. ábra) [4]. Kétoldali eltérés esetén szaruhártyahomályok családi halmozódása nem szerepelt

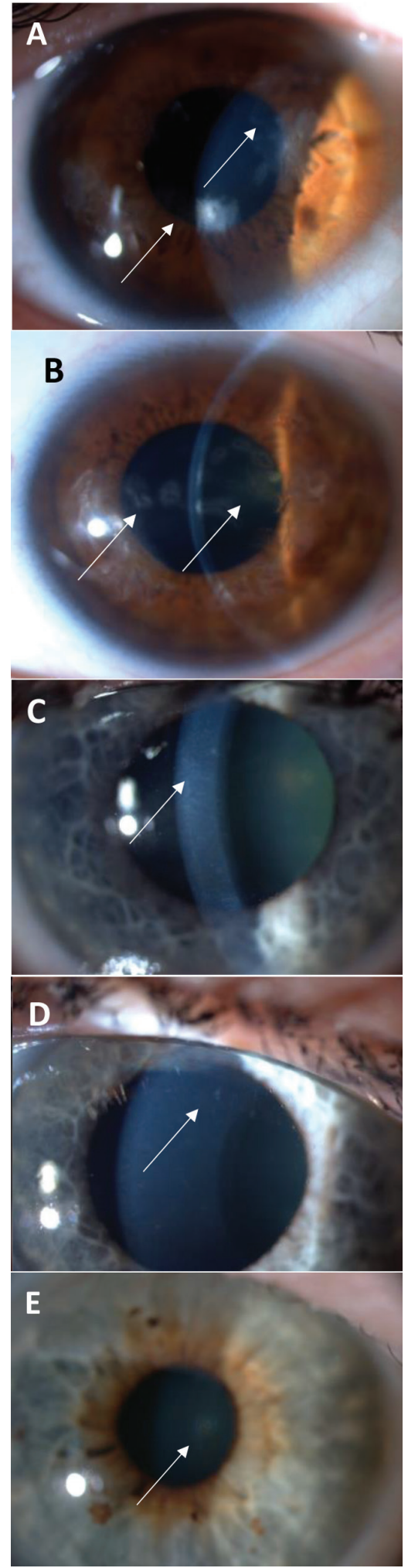

1. ábra

Szaruhártya-depozitumok (feltehetőleg immunglobulin-depo zíció) 3 beteg 5 szemében monoklonális gammopathiában. Éles, elágazó szélú praedescemetalis homályok 1 beteg mindkét szaruhártyájában „monoclonal gammopathy of ocular significance"-ben (MGOS) (A, B) [4], éles szélü, kerek vagy pontszerú, finom subepithelialis homályok egy myeloma multiplexszel diagnosztizált beteg mindkét szaruhártyájában $(\mathrm{C}, \mathrm{D})$, kerek stromalis homály myeloma multiplexszel diagnosztizált beteg egyik corneájában $(\mathrm{E})$

MGOS = szemészeti jelentőségú monoklonális gammopathia 
a kórelőzményben. A 3 betegból 2 egyénnél MM, míg 1 betegnél monoklonális gammopathia ocularis szignifikanciával (MGOS) volt a hematológiai diagnózis.

A gammopathiás betegeknél az egyéb szaruhártyahegek és -homályok között $6(7,14 \%)$ arcus senilis, 6 $(7,14 \%)$ 'crocodile shagreen' degeneráció, $4(4,76 \%)$ vaslerakódás és stromalis heg korábbi idegentest-eltávolítás miatt, $1(1,19 \%)$ Salzmann nodularis degeneráció, l $(1,19 \%)$ stromalis heg és kalcifikáció korábbi stromalis herpeses keratitis miatt volt megfigyelhető.

A szemészeti vizsgálati eredmények alapján a kontrollcsoportban leírtunk szárazszem-betegséget 32 (37,21\%), szürke hályogot 17 (19,76\%), macula- és/vagy retinadrusent $16(18,60 \%)$, krónikus szemhéjgyulladást 16 $(18,60 \%)$, szemészeti eltérés hiányát 14 (16,28\%), korábbi szürkehályog-mútétet 12 (13,95\%), Meibom-mirigy-diszfunkciót $10(11,63 \%)$, glaucomát $4(4,65 \%)$, diabeteses retinopathiát $4(4,65 \%)$, perifériás retinalis degenerációt 4 (4,65\%), hátsó kérgi szürke hályogot 3 $(3,49 \%)$, Fuchs-dystrophiát $2(2,33 \%)$, epiretinalis membránt $2(2,33 \%)$ és amblyopiát $1(1,16 \%)$ szemben.

A kontrollcsoportban az egyéb szaruhártyahegek és -homályok között arcus senilist 2 (2,33\%), 'crocodile shagreen'-t $2(2,33 \%)$, vaslerakódást és szaruhártyaheget korábbi idegentest-eltávolítás miatt $\mathrm{l}(1,16 \%)$ szemben találtunk. Az egyéb szaruhártyahegek és -homályok aránya szignifikánsan magasabb volt a monoklonális gammopathiát mutató csoportban, mint a kontrollok között $(\mathrm{p}=0,01)$.

\section{Megbeszélés}

Munkánkban megvizsgáltuk a monoklonális gammopathia szemészeti jeleit és szemészeti szövődményeit. Magyarországon évente megközelítőleg 350-400 új MM-es beteget fedeznek fel, és évente 120-150 autológcsontvelö-transzplantációra kerül sor MM miatt [26]. Érdekes megfigyelni, hogy monoklonális gammopathiás betegek között a szárazszem-betegség és a szürke hályog előfordulásának aránya szignifikánsan magasabb, valamint gyengébb BCVA- és magasabb OSDI-értékeket kapunk, mint az életkorban megegyező kontrolloknál.

$\mathrm{Az}$ általunk vizsgált gammopathiás betegcsoportban az átlagéletkor 63,83 év volt, a kontrolloké pedig 62,44 év. A szárazszem-betegség prevalenciája az általunk használt OSDI-kérdőív alapján $66,67 \%$ és $37,21 \%$ volt a két csoportban. A szárazszem-betegség prevalenciája az 50 év feletti korosztályban 5-34\% az irodalomban [27, 28], ami kontrollcsoportunk 37,21\%-os szárazszembetegségprevelanciájához közeli adat. Ugyanakkor a monoklonális gammopathiát mutató betegcsoportban a szárazszembetegség előfordulása $66,67 \%$ volt, és az OSDI-értékek is szignifikánsan magasabbak voltak a kontrollhoz viszonyítva. Ennek magyarázatául szolgálhat maga a hematológiai betegség vagy a megelőzően alkalmazott kortikoszteroidok és/vagy kemoterápiás szerek, melyek mellékhatásaként szárazszem-betegség már dokumentálásra került az irodalomban [29].

Habár a szürkehályog-mútéten átesett betegek százalékos aránya nem különbözött a gammopathiás és a kontrollcsoportban, a meg nem operált szürke hályogok/hátsó kérgi szürke hályogok aránya szignifikánsan magasabb volt a gammopathiások között $(19,76 \%$ vs. $55,95 \%$ és 3,49\% vs. 19,05\%). A szárazszem-betegséghez hasonlóan a szürke hályog kialakulásában szintén szerepe lehet a szisztémásan alkalmazott kortikoszteroidkezelésnek (monoklonális gammopathiában szenvedő plazmasejtes daganatos egyének gyakran hónapokon keresztül szisztémásszteroid-tartalmú kezelést kapnak, legföképpen az autológőssejt-átültetés előtti indukciós kezelés részeként), valamint a több ágensből álló mentő kemoterápiás kezelés során [30]. Emellett összefüggés lehetséges a monoklonális gammopathiával együtt járó fehérjeanyagcsere-változással. Chen és mtsai 50 évesnél idősebb, 6725 egyén esetében a szürke hályog prevalenciáját 23,1\%-ban határozták meg [31]. Monoklonális gammopathiát mutató betegpopulációnkban a szürke hályog prevalenciája több mint kétszerese volt a kontrolloknál talált aránynak, és szintén valamivel több mint kétszerese volt a Chen és mtsai által leírtaknak. A kortikoszteroidkezelésben nem részesült MGUS-os betegeknél a szürkehályog-prevalencia valamivel alacsonyabb volt.

A krónikus szemhéjszéli gyulladás prevalenciája 40 évnél idôsebb populációban $8,1 \%$ volt (Rim és mtsai) [32]. A gammopathiás alanyok között 14,29\%-ban fordult elő krónikus szemhéjgyulladás, melynek százalékos aránya nem különbözött a kontrollalanyokétól vagy érdemben az irodalmi adatoktól.

A Meibom-mirigy-diszfunkció prevalenciája az 50-59 éves korosztályban 36\%-ra tehetó [33]. Gammopathiás betegek esetében a Meibom-mirigy-diszfunkció előfordulása 20,24\%, míg a kontrollcsoportban valamivel kevesebb, 11,63\% volt. Az irodalmi adatokkal összehasonlítva egyik csoportban sem figyeltük meg a Meibommirigy-diszfunkció gyakoriságának növekedését.

Korábbi vizsgálatok kimutatták, hogy myeloproliferativ betegségekben szenvedő személyeknél felgyorsul a subretinalis drusenek felhalmozódása, és megnő a neovascularis időskori maculadegeneráció (AMD) kialakulásának rizikója [34]. Monoklonális gammopathia esetén maculopathiát és foveolaris druseneket írtak le [19]. Az általunk vizsgált személyeknél sem a gammopathiás, sem a kontrollcsoportban nem volt igazolható neovascularisatióval járó időskori maculadegeneráció. Emellett a macula- és retinadrusenek előfordulása a kontrollcsoportban majdnem kétszer magasabbnak adódott $(18,60 \%)$, mint a gammopathiás betegeknél $(9,52 \%)$, de szignifikáns különbség nem volt igazolható a két csoport között. Feltehetőleg egy, a jelenleginél nagyobb betegpopuláció vizsgálata adhat erre a későbbiekben magyarázatot. 
Garibaldi és mtsai [24] 2004-ben publikáltak egy esettanulmányt és irodalmi áttekintést 38 beteg vonatkozásában monoklonális gammopathiában szaruhártyalerakódások megjelenéséről. Az általunk vizsgált monoklonális gammopathiás betegek 5,95\%-ában találtunk a szaruhártyában olyan lerakódásokat, amelyek immunglobulin-lerakódásnak felelhetnek meg. A szaruhártyalerakódások aránya a betegek között így nem érte el a 6\%-ot. Ugyanakkor nem szabad megfeledkeznünk a szemészek rendkívül fontos szerepéről a paraproteinaemiás keratopathia felismerésében, hiszen így kimutathatóvá válik egy esetlegesen egyébként rejtve maradó hematológiai betegség.

A vizsgált gammopathiás betegek közül 2 beteg 4 szeménél (4,76\%) volt ismert glaucoma; 2 szemben $(2,38 \%)$ elsődleges nyílt zugú (OAG - open-angle glaucoma) és 2 szemben $(2,38 \%)$ elsődleges zárt zugú (ACG - angleclosure glaucoma) glaucoma volt megállapítható. Antón és mtsai [35] az OAG prevalenciáját 2,1\%-nak határozták meg 40-79 éves hispán betegekben. Bonomi és mtsai [36] Ausztriában az ACG prevalenciáját 0,6\%-nak írták le. A kontrollok körében szintén 4 szem esetében volt igazolható glaucoma (4,65\%). Ugyanakkor a glaucoma előfordulásának aránya a két csoportban nem különbözött, tehát a zöld hályog tekintetében a gammopathia hatása nem volt igazolható.

Epiretinalis membrán 5,95\%-ban fordult elő a gammopathiás csoportban, de aránya nem különbözött a kontrollokban igazolt 2,33\%-tól.

Monoklonális gammopathiát mutató betegségekben a vénás thromboembolia gyakori szövődmény a vér emelkedett viszkozitásának következtében [22, 37]. Ez jól látható pácienseink szemészeti leleteiben is: 1 beteg 1 szemében korábbi a. centralis retinae ágelzáródás és 1 beteg 1 szemében $\mathrm{v}$. centralis retinae ágelzáródás volt igazolható. Mindkét történés esetén elengedhetetlen a rendszeres szemészeti kontroll, mely bizonyos esetekben specifikus kezelést is igényel.

A szaruhártyában és kötőhártyában megjelenő immunglobulin-depozitumokon kívül más szemészeti eltéréseket is leírtak monoklonális gammopathiában [17]. Néhány közlemény monoklonális gammopathia és akut vagy krónikus uveitis egyidejü megjelenéséról számol be [18]. Ezenkívül beszámoltak az orbitalis zsírban és külső szemizmokban lerakódott monoklonális immunglobulin-kristályokról (kappa-könnyuulánc típusú), melyek invazív eltéréseket/szövetszaporulatokat okoznak (kristálytárolási histiocytosis). Szemhéjecchymosis is kialakulhat amyloidlerakódás következtében. Munteanu összefüggést írt le a Doyne retinalis dystrophia, a szaruhártya-lerakódások jelenléte és a jóindulatú monoklonális gammopathia között [21]. Ugyanakkor ezek a felsorolt szemészeti betegségek az általunk vizsgált betegekben nem voltak igazolhatók. Látható, hogy a monoklonális gammopathia a szemészeti jelek és szövődmények tekintetében is igen heterogén megjelenést mutat. Ez is amellett szól, hogy a betegek rendszeres, részletes szemészeti kontrollt igényelnek.

Összefoglalva, monoklonális gammopathiát mutató betegségekben a szárazszem-betegség és a szürke hályog a leggyakoribb szemészeti eltérés. A monoklonális gammopathia potenciális szemészeti jelei és szövődményei miatt javasoljuk a betegek évenkénti szemészeti ellenőrzését, életminőségük javítása érdekében.

Anyagi támogatás: A közlemény megírása, illetve a kutatómunka anyagi támogatásban nem részesült.

Szerzői munkamegosztás: K. Ki., K. Kl., Cs. A., S. G. L., G. L., C. C. N., T. G., M. G., V. G., Sz. N.: Adatgyưjtés. K. Ki., Sz. N., N. O.: Irodalomgyújtés. Sz. N., L. A.: Statisztikai elemzés. K. Ki., Sz. N., S. G. L., T. G., C. C. N., G. L., M. G., V. G., N. Z. Zs.: A kézirat szövegezése és javítása. A cikk végleges változatát valamenynyi szerző elolvasta és jóváhagyta.

Érdekeltségek: A szerzőknek nincsenek érdekeltségeik.

\section{Irodalom}

[1] International Myeloma Working Group, Kyle RA, Child A, Anderson K, et al. Criteria for the classification of monoclonal gammopathies, multiple myeloma and related disorders: a report of the International Myeloma Working Group. Br J Haematol. 2003; 121: 749-757.

[2] Nagy Z. Multiple myeloma and other plasma cell dyscrasias. [Mielóma multiplex és egyéb plazmasejtes diszkráziák.] Magy Onkol. 2016; 60: 154-163. [Hungarian]

[3] Szemlaky Zs, Mikala G. Waldenström's macroglobulinaemia and its individualized therapy options. [A Waldenström-macroglobulinaemia és betegségre szabott kezelése.] Orv Hetil. 2017; 158: 1604-1614. [Hungarian]

[4] Németh O, Tapasztó B, Tar S, et al. Corneal deposits in monoclonal gammopathy of undetermined significance. Review of the literature and case report. [Szaruhártya-lerakódások bizonytalan jelentőségú monoklonális gammopathiában. Irodalmi áttekintés és esetbemutatás.] Orv Hetil. 2018; 159: 1575-1583. [Hungarian]

[5] Rajkumar SV. Evolving diagnostic criteria for multiple myeloma. Hematology Am Soc Hematol Educ Program 2015; 2015: 272278.

[6] Landgren O, Kyle RA, Pfeiffer RM, et al. Monoclonal gammopathy of undetermined significance (MGUS) consistently precedes multiple myeloma: a prospective study. Blood 2009; 113 : 5412-5417.

[7] Kyle RA, Therneau TM, Rajkumar SV, et al. Prevalence of monoclonal gammopathy of undetermined significance. $\mathrm{N}$ Engl J Med. 2016; 354: 1362-1369.

[8] Nasr SH, Valeri AM, Cornell LD, et al. Renal monoclonal immunoglobulin deposition disease: a report of 64 patients from a single institution. Clin J Am Soc Nephrol. 2012; 7: 231-239.

[9] Zangari M, Zhan F, Tricot G. Bone and paraproteinemias. Curr Opin Support Palliat Care 2010; 4: 195-199.

[10] Steiner N, Schwärzler A, Göbel G, at al. Are neurological complications of monoclonal gammopathy of undetermined significance underestimated? Oncotarget 2017; 8: 5081-5091.

[11] Mathis S, Franques J, Richard L, at al. Monoclonal gammopathy of undeterminated significance and endoneurial IgG deposition: a case report. Medicine (Baltimore) 2016; 95: e4807. 
[12] Ramchandren S, Lewis RA. An update on monoclonal gammopathy and neuropathy. Curr Neurol Neurosci Rep. 2012; 12: $102-110$.

[13] Lichtman MA, Balderman SR. Unusual manifestations of essential monoclonal gammopathy. II. Simultation of the insulin autoimmune syndrome. Rambam Maimonides Med J. 2015; 6: e0027.

[14] Buxbaum JN, Genega EM, Lazowski P, et al. Infiltrative nonamyloidotic monoclonal immunoglobulin light chain cardiomyopathy: an underappreciated manisfestation of plasma cell dyscrasias. Cardiology 2000; 93: 220-228.

[15] Erciyestepe M, Tiryaki TO, Hindilerden IY, et al. A case with hepatic involvement mimicking metastatic disease in multiple myeloma. Case Rep Hematol. 2020; 2020: 5738319.

[16] Daoud MS, Lust JA, Kyle RA, et al. Monoclonal gammopathies and associated skin disorders. J Am Acad Dermatol. 1999; 40: $507-535$.

[17] Milman T, Kao AA, Chu D, et al. Paraproteinemic keratopathy. The expanding diversity of clinical and pathologic manifestations. Ophthalmology 2015; 122: 1748-1756.

[18] Barr CC, Gelender H, Font RL. Corneal crystalline deposits associated with dysproteinemia. Report of two cases and review of the literature. Arch Ophthalmol. 1980; 98: 884-889.

[19] Ormerod LD, Collin HB, Dohlman CH, et al. Paraproteinemic crystalline keratopathy. Ophthalmology 1988; 95: 202-212.

[20] Balderman SR, Lichtman MA. Unusual manifestations of monoclonal gammopathy. I. Ocular disease. Rambam Maimonides Med J. 2015; 6: e0026.

[21] Munteanu G. Doyne's macular heredodystrophy and benign monoclonal gammopathy. Genetic and pathogenetic correlations. [L'hérédodystrophie maculaire de Doyne et la gammopathie monoclonale bénigne. Corrélations génétiques et pathogéniques.] J Fr Ophtalmol. 1980; 3: 753-758. [French]

[22] Agorogiannis EI, Kotamarthi V. Paraproteinemia and central retinal vein occlusion. Hippokratia 2015; 19: 92.

[23] Nakazawa T, Yamaguchi K, Nakagawa Y, et al. Two cases of orbital myositis with monoclonal gammopathy of undetermined significance. Nippon Ganka Gakkai Zasshi 2004; 108: 110-117. [Japanese]

[24] Garibaldi DC, Gottsch J, de la Cruz Z, et al. Immunotactoid keratopathy: a clinicopathologic case report and a review of reports of corneal involvement in systemic paraproteinemias. Surv Ophthalmol. 2005; 50: 61-80. [Available online 25 December 2004]

[25] Lisch W, Saikia P, Pitz S, et al. Chameleon-like appearance of immunotactoid keratopathy. Cornea 2012; 31: 55-58.

[26] Varga G, Mikala G, Váróczy L, et al. Management of multiple myeloma in Hungary in 2016. [A myeloma multiplex megkö- zelítése Magyarországon 2016-ban.] Orv Hetil. 2016; 157: 123-137. [Hungarian]

[27] The epidemiology of dry eye disease: report of the Epidemiology Subcommittee of the International Dry Eye WorkShop. Ocul Surf. 2007; 5: 93-107.

[28] Dana R, Bradley JL, Guerin A, et al. Estimated prevalence and incidence of dry eye disease based on coding analysis of a large, all-age United States Health Care System. Am J Ophthalmol. 2019; 202: 47-54

[29] Kunkler AL, Binkley EM, Mantopoulos D, et al. Known and novel ocular toxicities of biologics, targeted agents, and traditional chemotherapeutics. Graefes Arch Clin Exp Ophthalmol. 2019; 257: 1771-1781.

[30] Fel A, Aslangul E, Le Jeunne C. Eye and corticosteroid's use. [Indications et complications des corticoïdes en ophtalmologie.] Presse Med. 2012; 41: 414-421. [French]

[31] Chen X, Zhou DY, Shen J, et al. Prevalence and risk factors on age-related cataract and surgery in adults over 50 years old in Binhu District, Wuxi, China. Int J Ophthalmol. 2020; 13: 445451.

[32] Rim TH, Kang MJ, Choi M, et al. Ten-year incidence and prevalence of clinically diagnosed blepharitis in South Korea: a nationwide population-based cohort study. Clin Exp Ophthalmol. 2017; 45: 448-454.

[33] Gao JG, Chen J, Tang Y, et al. Prevalence of meibomian gland dysfunction in staffs and faculty members of a Chinese university. Int J Ophthalmol. 2020; 13: 1667-1670.

[34] Liisborg C, Nielsen MK, Hasselbalch HC, et al. Patients with myeloproliferative neoplasms and high levels of systemic inflammation develop age-related macular degeneration. EClinicalMedicine 2020; 26: 100526

[35] Antón A, Andrada MT, Mujica V, et al. Prevalence of primary open-angle glaucoma in a Spanish population: the Segovia study. J Glaucoma 2004; 13: 371-376.

[36] Bonomi L, Marchini G, Marraffa M, et al. Epidemiology of angle-closure glaucoma: prevalence, clinical types, and association with peripheral anterior chamber depth in the Egna-Neumarkt Glaucoma Study. Ophthalmology 2000; 107: 998-1003.

[37] Kristinsson SY, Fears TR, Gridley G, et al. Deep vein thrombosis after monoclonal gammopathy of undetermined significance and multiple myeloma. Blood 2008; 112: 3582-3586.

(Kormányos Kitti dr., Budapest, Mária u. 39., 1085 e-mail: kitti0820@gmail.com)

A cikk a Creative Commons Attribution 4.0 International License (https://creativecommons.org/licenses/by/4.0/) feltételei szerint publikált Open Access közlemény, melynek szellemében a cikk bármilyen médiumban szabadon felhasználható, megosztható és újraközölhetö, feltéve, hogy az eredeti szerző és a közlés helye, illetve a CC License linkje és az esetlegesen végrehajtott módosítások feltüntetésre kerülnek. (SID_1) 